\title{
Electrophoretic separation of inorganic anions with an anion complexone-modified capillary column
}

\author{
Chuen-Ying Liu*, Wei-Hsi Chen \\ Department of Chemistry, National Taiwan University, P.O. Box 23-34, Roosevelt Road Section 4, No. 1, Taipei 10764, Taiwan
}

Received 23 March 1998; received in revised form 25 May 1998; accepted 2 June 1998

\begin{abstract}
A twenty-eight-membered macrocyclic polyamine, 4,8,12,18,22,26-hexaaza-1,15-dioxacyclooctaeicosane ([28]ane- $\left.\mathrm{N}_{6} \mathrm{O}_{2}\right)$, was covalently bound to fused-silica for the electrophoretic separation of simple anions, complex anions and metalcontaining anions. Parameters influencing bound ligand complexation properties or the electrophoretic behavior of analytes, such as the nature of the background electrolyte, the $\mathrm{pH}$ and concentration were investigated. The separation of metallocyanide complexes, $\mathrm{Fe}(\mathrm{CN})_{6}^{3-}$ and $\mathrm{Fe}(\mathrm{CN})_{6}^{4-}$ has been achieved. Supercomplex formation resulting from the second-sphere interaction between metallocyanide and polyamine was indicated. The method was effective for the separation of arsenite, arsenate, dimethylarsinic acid and phenylarsonic acid or selenite as well as selenate species. Better resolution of a mixture of bromide, chloride, sulfate, nitrate, bromate and iodate was achieved using an applied potential of $-20 \mathrm{kV}$, with chromate $(5 \mathrm{mM}, \mathrm{pH} 8.1)$ as background electrolyte and indirect detection at $270 \mathrm{~nm}$. Linearity of response, expressed as peak height or peak area was in the range of $10^{-5}-10^{-6} \mathrm{M}$; detection limits (LODs) based on three times signal-to-noise ratio for bromide, chloride, sulfate, nitrate, bromate, iodate, selenate and selenite were all at the femtomole levels. The anions present in mineral water and rainwater were also analyzed to evaluate the quantitative performance of the proposed method. The response mechanism of the prepared capillary column was briefly discussed in terms of anion complex formation between analytes and the protonated [28]ane- $\mathrm{N}_{6} \mathrm{O}_{2}$ bound at the silica surface. (C) 1998 Elsevier Science B.V. All rights reserved.
\end{abstract}

Keywords: Capillary columns; Water analysis; Polyamine-bound fused-silica columns; Inorganic anions; Metallocyanides

\section{Introduction}

Ion chromatography is now a well-established method for the analysis of inorganic anions; however, it is difficult to separate halides, oxyhalides and metal oxoacids in a short analysis time. In a conventional anion-exchange column, halides and oxyhalides elute early and tend to be poorly resolved, while metal oxoacids are strongly retained on the

\footnotetext{
*Corresponding author.
}

column since they are polyvalent anions and they also behave like hydrophobic species by interacting with packing materials [1]. Capillary electrophoresis (CE) offers the possibility of separating ionic compounds with high separation efficiencies and short analysis times. However, there is one drawback for anion analysis, especially for those which can migrate very fast in the direction opposite to an electroosmotic flow (EOF). In order to solve this difficulty, some methods have been developed. They are based on reversing or suppressing the EOF 
effectively with a dynamic coating of the surface of silica capillary with long chain quaternary ammonium ions [2-4], using a polymer-coated capillary $[1,5,6]$, using a low-pH migrating solution containing sodium sulfate [7], or with the addition of a macrocycle [8,9]. Another problem in the inorganic analyses is that in most cases analyses of anionic substances in CE have been done by an indirect detection method, using chromate ion. The methods with a coating reagent and an indirect photometric reagent possess undesirable problems, such as noisiness and instability of baseline, lower reproducibility and low sensitivity of detection, which result in a poorer detection limit for analytes [7].

Since Jorgenson and Lukacs [10] and Knox and Grant $[11,12]$ demonstrated the potential of packedcapillary electrochromatography (CEC), this new technique has become an attractive method, combining the high efficiency of capillary electrophoresis with the high selectivity usually obtained in highperformance liquid chromatography. Considerable effort has been expended on column technology both for open tubes and packed columns. Several coating materials have been used to prepare columns for open tubular capillary electrochromatography for reversed-phase, normal-phase and chiral separations [13-26], but few are suitable for the separation of inorganic species.

In recent years anion coordination chemistry has been developed as a new area of coordination chemistry. This arose from the design of anion receptor molecules of various types, especially macrocyclic and macropolycyclic polycations capable of forming strong and selective complexes with inorganic anions or carboxylate and phosphate of organic or biological substrates [27]. These compounds behave as anionic receptors because of their ability to form charged species in aqueous solution even at neutral $\mathrm{pH}$ and because of their capability to form multisite hydrogen bond networks. Hence these reagents are useful analytically for selective recognition of inorganic and organic anions in addition to complexing cationic species [28,29].

In order to reduce detection interference and to increase the selectivity for the anionic species, a 24-membered macrocyclic polyamine [24]ane- $\mathrm{N}_{6}$ bonded phase has been prepared for the electrophoretic separation of inorganic and organic anions
[30]. In the present work, a larger azamacrocycle, the 28-membered macrocyclic polyamine, 4, 8, 12, 18, 22, 26-hexaaza-1, 15-dioxacyclooctaeicosane ([28]ane- $\mathrm{N}_{6} \mathrm{O}_{2}$ ) which seemed more promising in anion coordination has been prepared and employed for the electrophoretic separation and quantitation of a group of inorganic anions of potential interest in a variety of environmental and biological samples.

\section{Experimental}

\subsection{Apparatus}

A high-voltage power supply with a $30 \mathrm{kV}$ capacity (Model 890-CE, Jasco, Tokyo, Japan), a variable-wavelength UV-Vis detector (Jasco 870CE) and an integrator (Jasco 807-IT) were employed for capillary electrophoresis. The separations were carried out on a fused-silica capillary column with an external coating of polyimide (J\&W Scientific, Folsom, CA, USA) and chemically modified with a 28-membered macrocyclic ligand containing oxygen and nitrogen as donor atoms as described below. The modified capillaries were of $75 \mu \mathrm{m}$ I.D. and the total length of the capillary was $70 \mathrm{~cm}$ with a distance of $50 \mathrm{~cm}$ between the injection end and the detection window. Detection was by indirect UV absorbance at $270 \mathrm{~nm}$.

Elemental analyses were carried out with a Perkin-Elmer (Norwalk, CT, USA) Model 2400 elemental analyzer performed by the Elemental Analyses Service Center of NSC at the National Taiwan University. IR spectra were obtained on a Perkin-Elmer Model 983 spectrophotometer. ${ }^{1} \mathrm{H}$ NMR spectra were measured on a Bruker (Karlsruhe, Germany) AC-200 spectrometer at $200 \mathrm{MHz}$. Mass spectra were measured with a JEOL SX-102 A mass spectrometer.

\subsection{Reagents and chemicals}

Most chemicals were of analytical reagent grade from Merck (Darmstadt, Germany). Purified water (18 M $\Omega$-cm) from a Milli-Q water purification system (Millipore, Bedford, MA, USA) was used to prepare all solutions. $\gamma$-Glycidoxypropyltri- 
methoxysilane was obtained from Aldrich (Milwaukee, WI, USA). All liquid reagents and solvents used in moisture-sensitive reactions were distilled and collected over type $4(4 \AA)$ molecular sieves.

\subsection{Synthesis of 4,8,12,18,22,26-hexaaza-1,15- dioxacyclooctaeicosane ([28]ane- $\mathrm{N}_{6} \mathrm{O}_{2}$ )}

This compound was prepared by the following procedure.

\subsubsection{Preparation of $N, N^{\prime}$, 4-tri(p-toluene- sulfonyl)-4-azaheptanediamine (I)}

3,3'-Diaminodipropylamine (20 g) and triethylamine $(35 \mathrm{~g})$ in dichloromethane $(300 \mathrm{ml})$ were placed in a three-necked bottle (1 1) with efficient stirring at $50^{\circ} \mathrm{C}$, then 4-toluenesulfonyl chloride $(116$ $\mathrm{g})$ in dichloromethane $(200 \mathrm{ml})$ was added dropwise to the reaction mixture and refluxed for $6 \mathrm{~h}$. The product was isolated by extraction twice with a mixture of ice-hydrochloric acid and pure water. The dichloromethane layer was dried with anhydrous magnesium sulfate and concentrated under reduced pressure. Purification by recrystallization from ethanol gave white crystals of $\mathbf{I}$ (76 g, yield 85\%). m.p. $118-120^{\circ} \mathrm{C} .{ }^{1} \mathrm{H}$ NMR $\left(\mathrm{C}^{2} \mathrm{HCl}_{3}\right): \delta 1.72(t, 4 \mathrm{H}, 2$ $\left.\mathrm{CH}_{2}-\mathrm{CH}_{2}-\mathrm{CH}_{2}\right), 2.43\left(2 s, 9 \mathrm{H}, 1 \mathrm{CH}_{3}\right.$ and $2 \mathrm{CH}_{3}$ of tosyl), 2.92 and $3.12\left(2 t, 8 \mathrm{H}, 4 \mathrm{CH}_{2}-\mathrm{N}\right) .5 .0$ (br., 2 $\mathrm{H}, 2 \mathrm{NH}), 7.4,7.7,7.85(\mathrm{~m}, 12 \mathrm{H}$, arom. H). Anal. calc. for $\mathrm{C}_{27} \mathrm{H}_{35} \mathrm{~N}_{3} \mathrm{O}_{6} \mathrm{~S}_{3}$ (593.7): C 54.61, H 5.94, N 7.08\%; found: C 54.66, H 6.12, N 6.90\%.

\subsubsection{Preparation of 6,10,14-tri(4-toluenesulfonyl)- 6,10,14-triaza-3,17-dioxanonadecane-1,19-diol (II)}

The tritosyl derivative of 4-azaheptanediamine (I) was the starting material for the two linear parts used in the cyclization step. A mixture of compound I (20 $\mathrm{g})$ and potassium carbonate $(25 \mathrm{~g})$ in $N, N$-dimethylformamide (DMF) $(200 \mathrm{ml})$ was treated with 2-(2chloroethoxy)ethanol $(10 \mathrm{~g})$ in dimethylforamide (50 $\mathrm{ml}$ ) which was added dropwise over a period of $1 \mathrm{~h}$ at $110^{\circ} \mathrm{C}$ for $24 \mathrm{~h}$. The product was allowed to cool and isolated from unreacted potassium carbonate. The solvent was evaporated under reduced pressure and the residue was partitioned between water and dichloromethane. The organic layer was dried over $\mathrm{MgSO}_{4}$ and evaporated under reduced pressure. Purification by silica gel column chromatography with methanol-dichloromethane $(1: 99, \mathrm{v} / \mathrm{v})$ as mobile phase gave a pale yellow oil (II) (15 g, yield $60 \%) .{ }^{1} \mathrm{H}$ NMR $\left(\mathrm{C}^{2} \mathrm{HCl}_{3}\right): \delta 1.85\left(m, 4 \mathrm{H}, 2 \mathrm{CH}_{2}-\right.$ $\left.\mathrm{CH}_{2}-\mathrm{CH}_{2}\right), 2.41\left(s, 9 \mathrm{H}, 3 \mathrm{CH}_{3}\right.$ of tosyl), 3.0 3.25 $\left(m, 12 \mathrm{H}, 6 \mathrm{CH}_{2}-\mathrm{N}\right), 3.4 \sim 3.7\left(m, 12 \mathrm{H}, 6 \mathrm{CH}_{2}-\mathrm{O}\right)$, 7.2 7.7 $(m, 12 \mathrm{H}$, arom. H). Anal. calc. for $\mathrm{C}_{35} \mathrm{H}_{51} \mathrm{~N}_{3} \mathrm{O}_{10} \mathrm{~S}_{3}$ (769.9): C 54.59, H 6.67, N 5.48\%; found: C 53.24, H 6.60, N 5.46\%.

\subsubsection{Preparation of 1,19-di(methanesulfonyloxy)- 6,10,14-tri(4-toluenesulfonyl)-6,10,14-triaza-3,17- dioxanonadecane (III)}

Compound II $(10 \mathrm{~g})$ and triethylamine $(8 \mathrm{~g})$ in dichloromethane $(200 \mathrm{ml})$ were placed in a roundbottomed flask and reacted at $-18^{\circ} \mathrm{C}$ with stirring. Methanesulfonyl chloride (4 g) in dichloromethane $(20 \mathrm{ml})$ was added dropwise and stirring was continued for another $2 \mathrm{~h}$. The material was allowed to come to room temperature and washed with $1 \mathrm{M}$ hydrochloric acid and saturated sodium chloride solution. The organic layer was dried over anhydrous $\mathrm{MgSO}_{4}$ and evaporated under reduced pressure to leave a yellow oil (III) (12 g, yield 90\%). ${ }^{1} \mathrm{H}$ NMR $\left(\mathrm{C}^{2} \mathrm{HCl}_{3}\right): \delta 1.90\left(b r ., 4 \mathrm{H}, 2 \mathrm{CH}_{2}-\mathrm{CH}_{2}-\mathrm{CH}_{2}\right), 2.41$ (s, 9H, $3 \mathrm{CH}_{3}$ of tosyl), $3.01\left(s, 6 \mathrm{H}, 2 \mathrm{CH}_{3}\right.$ of $\mathrm{Ms}$ ). $3.05 \sim 3.25\left(m, 12 \mathrm{H}, 6 \mathrm{CH}_{2}-\mathrm{N}\right), 3.55 \sim 3.75(m, 8 \mathrm{H}$, $\left.4 \mathrm{CH}_{2}-\mathrm{O}\right), 4.3\left(s, 4 \mathrm{H}, 2 \mathrm{CH}_{2}-\mathrm{OMs}\right) 7.2 \sim 7.7(\mathrm{~m}, 12$ $\mathrm{H}$, arom. H). Anal. calc. for $\mathrm{C}_{35} \mathrm{H}_{51} \mathrm{~N}_{3} \mathrm{O}_{10} \mathrm{~S}_{3}$ (926.1): C 47.98, H 5.99, N 4.54\%; found: C 48.46, H 5.97, N 5.01\%.

\subsubsection{Preparation of 4,8,12,18,22,26-hexa(4- toluenesulfonyl)-4,8,12,18,22,26-hexaaza-1,15- dioxacyclooctaeicosane $(\boldsymbol{V})$}

In a $500 \mathrm{ml}$ round-bottomed flask were placed compound I (7 g), sodium hydride (1.86 g) and DMF $(150 \mathrm{ml})$. After stirring for $30 \mathrm{~min}$, the unreacted sodium hydride was removed by filtration. The filtrate (IV) was heated at $100^{\circ} \mathrm{C}$, then III $(10 \mathrm{~g})$ in DMF $(150 \mathrm{ml})$ was added dropwise over $1 \mathrm{~h}$ and heating was continued for further $2 \mathrm{~h}$. The mixture was stirred overnight, the solvent was then evaporated under reduced pressure and the mixture was partitioned between dichloromethane and $1 \mathrm{M} \mathrm{HCl}$. The organic layer was dried over $\mathrm{MgSO}_{4}$. Evaporation gave the crude product. The product (V) was purified by chromatography on silica gel with methanol-dichloromethane $(2: 98, \mathrm{v} / \mathrm{v})$. Recrystallization 
was from dichloromethane-absolute ethanol (5 g, yield $35 \%)$. m.p. $205 \sim 207^{\circ} \mathrm{C} .{ }^{1} \mathrm{H}$ NMR $\left(\mathrm{C}^{2} \mathrm{HCl}_{3}\right): \delta$ 1.9 2.0 (br., $\left.8 \mathrm{H}, 4 \mathrm{CH}_{2}-\mathrm{CH}_{2}-\mathrm{CH}_{2}\right), 2.42(s, 18 \mathrm{H}$, $6 \mathrm{CH}_{3}$ of tosyl), 3.0 3.3 (m, $\left.24 \mathrm{H}, 12 \mathrm{CH}_{2}-\mathrm{N}\right)$. 3.5 3.65 (m, $\left.8 \mathrm{H}, 4 \mathrm{CH}_{2}-\mathrm{O}\right), 7.2 \sim 7.7(m, 24 \mathrm{H}$, arom. H). Anal. calc. for $\mathrm{C}_{62} \mathrm{H}_{82} \mathrm{~N}_{6} \mathrm{O}_{14} \mathrm{~S}_{6}$ (1327.7): C 56.09, H 6.23, N 6.33\%; found: C 54.56, H 6.38, N $6.28 \%$.

\subsubsection{Preparation of 4,8,12,18,22,26-hexaaza- \\ 1,15-dioxacyclooctaeicosane}

Compound V (2 g), phenol (2.85 g) and a mixture of hydrobromic acid and acetic acid (33\%, $50 \mathrm{ml})$ were placed in a round-bottomed flask and heated at $80^{\circ} \mathrm{C}$ for $14 \mathrm{~h}$. The mixture was cooled to room temperature. After evaporation, the residue was partitioned between water and dichloromethane. The water layer was concentrated under reduced pressure. Purification by ion-exchange chromatography on Dowex 1-X8 followed by recrystallization from ethanol in hydrochloric acid solution gave white crystals of [28]ane- $\mathrm{N}_{6} \mathrm{O}_{2}$ (compound VI) $(0.8 \mathrm{~g}$, yield $85 \%$ ). m.p. $>250^{\circ} \mathrm{C}$ and decomposed above $300^{\circ} \mathrm{C} .{ }^{1} \mathrm{H}$ NMR $\left({ }^{2} \mathrm{H}_{2} \mathrm{O}\right): \delta 2.15\left(m, 8 \mathrm{H}, 4 \mathrm{CH}_{2}-\right.$ $\left.\mathrm{CH}_{2}-\mathrm{CH}_{2}\right), 3.23\left(t, 16 \mathrm{H}, 8 \mathrm{CH}_{2}-\mathrm{CH}_{2}-\mathrm{N}\right), 3.33(t, 8$ $\left.\mathrm{H}, 4 \mathrm{O}-\mathrm{CH}_{2}-\mathrm{CH}_{2}-\mathrm{N}\right) .3 .75\left(t, 8 \mathrm{H}, 4 \mathrm{CH}_{2}-\mathrm{O}\right)$. Anal. calc. for $\mathrm{C}_{20} \mathrm{H}_{46} \mathrm{~N}_{6} \mathrm{O}_{2} \cdot 6 \mathrm{HCl}$ (618.2): C 38.66, $\mathrm{H}$ 8.48, N 13.52\%; found: C 36.33, H 8.28, N $11.34 \%$. Mass spectra: found 202.4, assign $\mathrm{C}_{10} \mathrm{H}_{23} \mathrm{~N}_{3} \mathrm{O}^{+} \quad$ ([14]ane- $\left.\mathrm{N}_{3} \mathrm{O}^{+}\right), \quad 201$ and $\mathrm{C}_{20} \mathrm{H}_{46} \mathrm{~N}_{6} \mathrm{O}_{2}^{2+} \quad$ ([28]ane- $\left.\mathrm{N}_{6} \mathrm{O}_{2}^{2+}\right): 402 / 2$; found 403.3, assign. $\mathrm{C}_{20} \mathrm{H}_{46} \mathrm{~N}_{6} \mathrm{O}_{2}^{+}$([28]ane- $\left.\mathrm{N}_{6} \mathrm{O}_{2}^{+}\right), 402$; found 440.1, assign. $\mathrm{C}_{20} \mathrm{H}_{46} \mathrm{~N}_{6} \mathrm{O}_{2} \cdot \mathrm{HCl}^{+}$([28]ane$\left.\mathrm{N}_{6} \mathrm{O}_{2} \cdot \mathrm{HCl}^{+}\right) 438$.

\subsection{Coating of Capillaries with $\gamma$ - Glycidoxypropyltrimethoxysilane}

Fused-silica capillaries $(75 \mathrm{~cm} \times 75 \mathrm{~cm}$ I.D.) were first flushed with $1 \mathrm{M} \mathrm{KOH}$ (30 min), then pure water $(15 \mathrm{~min}), 1 \mathrm{M} \mathrm{HCl}(30 \mathrm{~min})$ and pure water (15 min). The capillaries were purged with nitrogen for $20 \mathrm{~min}$, then dried at $110^{\circ} \mathrm{C}$ overnight. For coating, the capillary was filled with a $10 \%(\mathrm{w} / \mathrm{v})$ solution of $\gamma$-glycidoxypropyltrimethoxysilane in toluene. The capillary was kept for $3 \mathrm{~h}$ at $110^{\circ} \mathrm{C}$ for silylization. After purging with toluene to remove unreacted reagent for several min, the capillaries were dried in a vacuum oven. The capillary was then filled with a $1 \%(\mathrm{w} / \mathrm{v})$ solution of the macrocyclic compound, [28] ane- $\mathrm{N}_{6} \mathrm{O}_{2} \cdot 6 \mathrm{HCl}$ in DMF. After standing for $10 \mathrm{~h}$ at $120^{\circ} \mathrm{C}$ for functionalization, the dried capillaries were purged with methanol and pure water for several min before equilibration with buffer solution. They were then ready for use.

\subsection{Sample injection}

The moles of each ion taken into the capillary in $t$ $\mathrm{s}$ are calculated by the following equations [31]: moles injected $=\mu_{\text {app }}\left(E \times \kappa_{\mathrm{b}} / \kappa_{\mathrm{s}}\right) t \pi r^{2} C$, where $\mu_{\text {app }}$ is the apparent mobility of analyte, $E$ is the applied electric field, $r$ is the capillary radius, $C$ is the sample concentration $\left(\mathrm{mol} \mathrm{l}^{-1}\right)$ and $\kappa_{\mathrm{b}} / \kappa_{\mathrm{s}}$ is the ratio of conductivities of the buffer and sample.

\section{Results and discussion}

\subsection{Characterization of the bonded capillary column}

Procedures for preparing a new capillary column are outlined in Fig. 1. The presence of functional groups in the capillaries was confirmed from their IR data. For measuring IR spectra, the external coating of polyimide was removed prior to grinding and a higher ratio of bonded phase capillary to potassium bromide than the conventional one was used for blending. Specific evidence of covalently bound [28] ane- $\mathrm{N}_{6} \mathrm{O}_{2}$ is provided by IR absorption due to the $\mathrm{N}-\mathrm{H}$ stretching $\left(3447 \mathrm{~cm}^{-1}\right), \mathrm{N}-\mathrm{H}$ bending $\left(1646 \mathrm{~cm}^{-1}\right)$ and a readily identifiable peak around $2920 \mathrm{~cm}^{-1}$ due to the aliphatic $\mathrm{C}-\mathrm{H}$ stretching. Since the nature of the chemical group bound to the column surface, the degree of surface deactivation and the phase thickness determine the dependence of the EOF on $\mathrm{pH}$, and also the direction of EOF, quantification of EOF was used to measure the effectiveness of bonding procedures [32]. The EOF velocities of both bonded phase and bare fused-silica were determined, according to the migration time of benzyl alcohol which served as a neutral marker [33]. Here the sample injection for bare capillary was made from the positive end, while that for bonded phases was from negative end. Fig. 2 provides a 
(a)

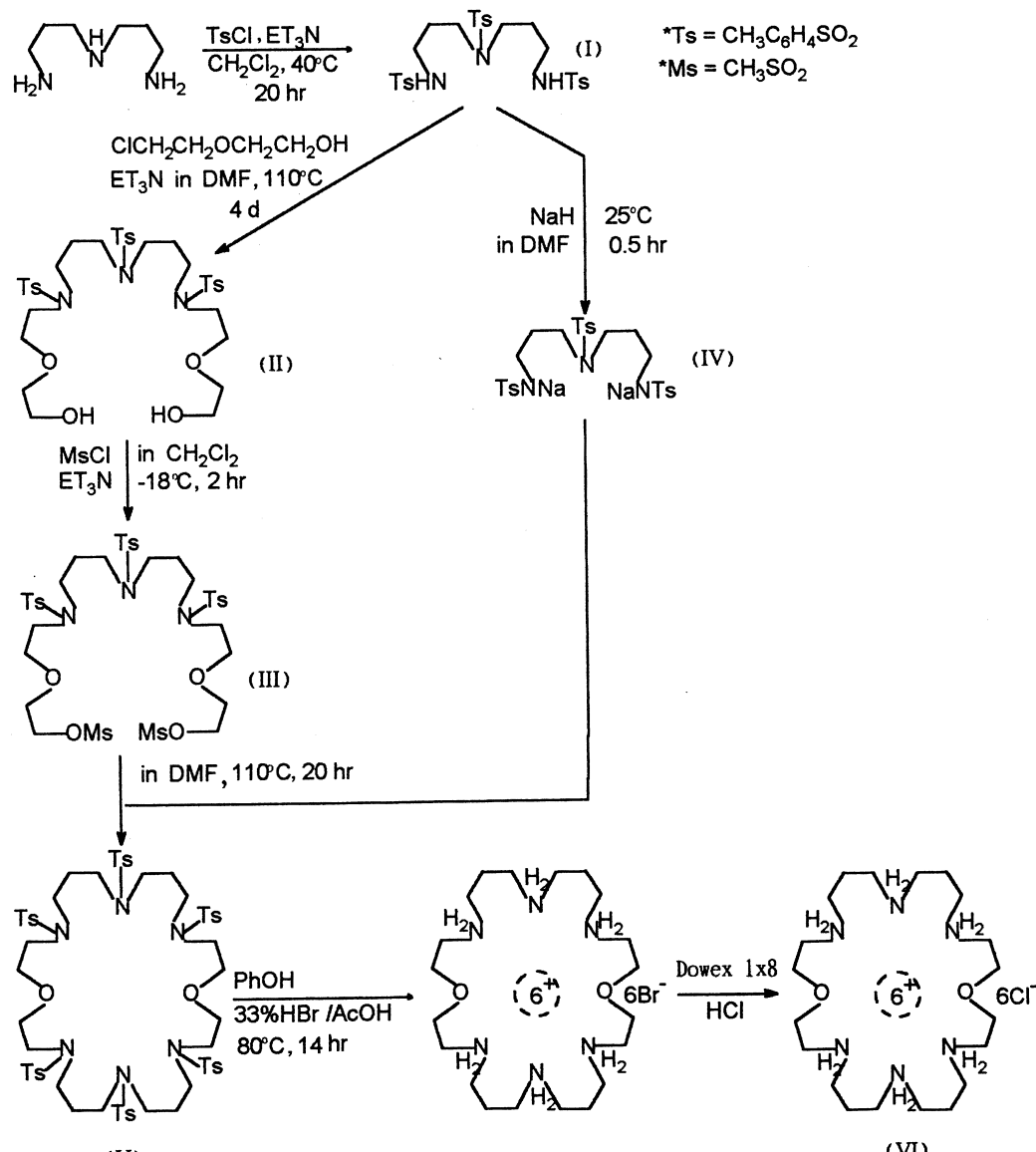

(V)

(VI)

(b)
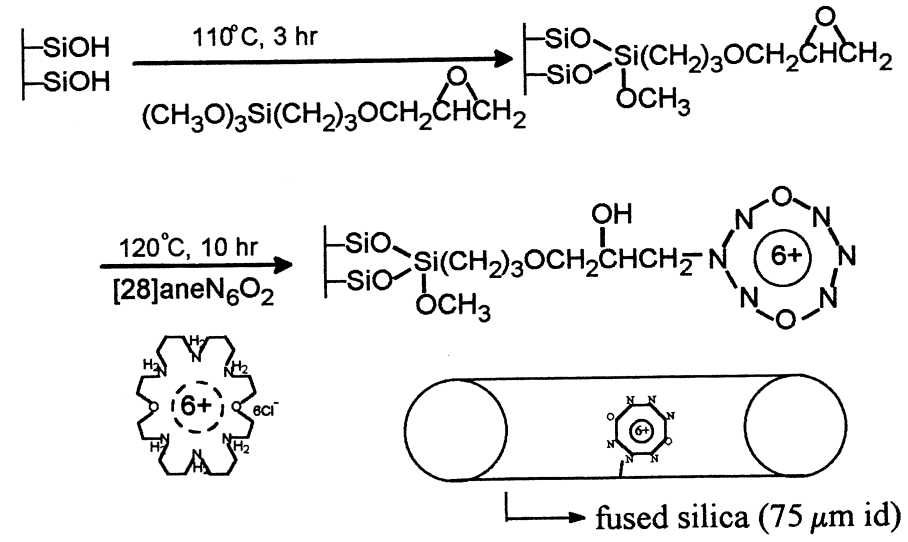

Fig. 1. Procedures for covalent surface modification of the fused-silica capillary column. 


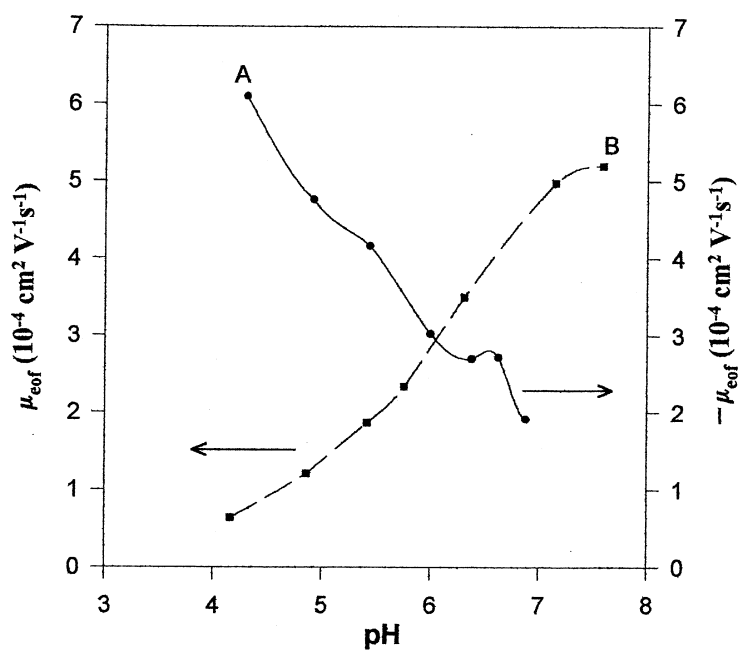

Fig. 2. Effect of pH on electroosmotic flow mobility in various capillary materials. Curve A: Covalent surface modification with polyamine, [28]ane- $\mathrm{N}_{6} \mathrm{O}_{2}$ fused-silica capillary. Curve B: Untreated fused-silica capillary.

dramatic difference in $\mathrm{pH}$ dependence between the two capillaries. For the bare capillary the electroosmotic flow-rate increases with $\mathrm{pH}$ because of a larger degree of dissociation of silanol groups on the capillary wall. Moreover for the capillary bonding with [28] ane- $\mathrm{N}_{6} \mathrm{O}_{2}$ group the EOF is reversed and the migration velocity increases as the $\mathrm{pH}$ decreases. This can be accounted for by the finding from silica modification that it is mainly the amino groups of the macrocyclic compound which are protonated at a lower $\mathrm{pH}$ value. A stable flow over the $\mathrm{pH}$ range 6 6.5 (Fig. 2) was observed which might be corresponding to the protonation constants, $\mathrm{p} K_{1}$ of the [28] ane- $\mathrm{N}_{6} \mathrm{O}_{2}$. We must mention that [28] ane- $\mathrm{N}_{6} \mathrm{O}_{2}$ is a new compound and no data is available for the reference. This conclusion is considered to arise from the comparison of a series of macrocyclic polyamines $\left(\mathrm{p} K_{1}\right.$ values in parentheses except [32]$\mathrm{N}_{8}$ which has eight protons): [32] $-\mathrm{N}_{8}\left(\mathrm{p} K_{3}, 7.55\right)$, [27] ane $-\mathrm{N}_{6} \mathrm{O}_{3}$ (5.70), [24]ane- $\mathrm{N}_{6}$ (6.40), [24]ane$\mathrm{N}_{6} \mathrm{O}_{2}$ (3.40) and [18]ane- $\mathrm{N}_{6}(\sim 1)$ [34-36]. This may be explained by the fact that a larger azacycle with more oxygen donor atoms may exhibit an easier protonation character, resulting in a greater $\mathrm{pK}$ value. According to this explanation, the EOF should roll off to a constant value at $\mathrm{pH}<6.5$. The observation (Fig. 2) is unexpected and it appears to be rising steeply at $\mathrm{pH}$ 4. An increase in the number of protonated silanol groups as the $\mathrm{pH}$ decreases leads to an additional EOF.

\subsection{Separation of metal complexes}

In order to get further information to characterize the prepared bonded phase capillary column, electrophoretic separation of a mixture of ferrocyanide and ferricyanide was investigated. Preliminary test showed that effective separation of these two ions could be achieved at $\mathrm{pH}$ values greater than 7 . Although at lower $\mathrm{pH}$ region, where the polyamines are more protonated and the more stable complexes can be formed. Meanwhile a greater EOF was provided. But a poor resolution for the separation was indicated. Hence at higher $\mathrm{pH}$ region was selected as the separation condition. The separation performed at $\mathrm{pH} 10.4$ with a phosphate buffer (10 $\mathrm{m} M$ ) and direct UV detection at $220 \mathrm{~nm}$ is shown in Fig. 3. Both ions are similar in chemical structure (octahedral complex) and molecular mass, different only in ionic charge. The ionic mobility of ferrocyanide and ferricyanide are $11.45 \cdot 10^{-4}$ and $10.47 \cdot 10^{-4} \mathrm{~cm}^{2} \mathrm{~s}^{-1} \mathrm{~V}^{-1}$, respectively [31]. Hence ferrocyanide would be expected to migrate faster than ferricyanide as shown in Buchberger and Haddad's work, in which a bare fused-silica capillary column and a phosphate buffer of $\mathrm{pH} 8.5$ with the addition of hexamethonium bromide were employed for the separation [37]. However, the migration of $\mathrm{Fe}(\mathrm{CN})_{6}^{3-}(8.3 \mathrm{~min})$ is faster than that of $\mathrm{Fe}(\mathrm{CN})_{6}^{4-}$ (9.3 $\mathrm{min})$ in our work. Different separation mechanisms are clearly indicated. We must mention, at the separation condition, neutral marker migrates very slow and a lengthy time was necessary to detect it. The phenomenon can be explained by the little contribution of EOF and the mechanism of anion coordination playing a more important role in the separation.

The expression 'supercomplexes' has been used to describe the second-sphere coordination between the $\left[\mathrm{M}^{n+}(\mathrm{CN})_{6}\right]^{(6-n)-} \quad[\mathrm{M}=\mathrm{Fe}(\mathrm{II}), \quad \mathrm{Fe}(\mathrm{III}), \quad \mathrm{Co}(\mathrm{III})$, $\mathrm{Ru}$ (III) etc.] anions and the polyammonium macrocyclic receptors [36]. Hosseini reported the stability constants of $\left[\mathrm{M}^{n+}(\mathrm{CN})_{6}\right]^{(6-n)-}$ toward macrocyclic polyamines of different ring size determined 
A

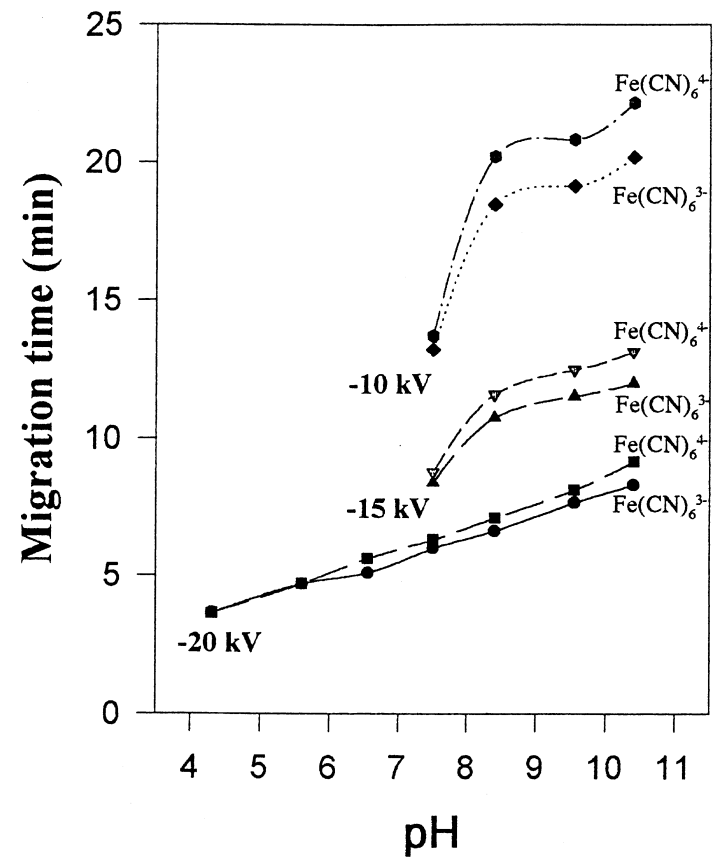

B

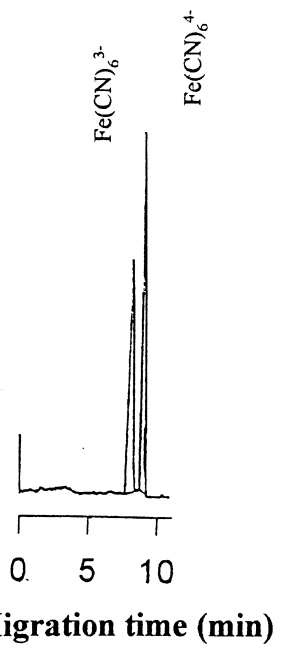

Fig. 3. (A) Migration time of metallocyanides as a function of acidity. Column: Covalent surface modification with polyamine, [28] ane $-\mathrm{N}_{6} \mathrm{O}_{2}$ fused-silica capillary $(50 \mathrm{~cm} \times 75 \mu \mathrm{m}$ I.D.). Background electrolyte: phosphate buffer $(10 \mathrm{~m} M)$. Sample concentration: $\left[\mathrm{Fe}(\mathrm{CN})_{6}^{3-}\right.$ ]: $10 \mu M ;\left[\mathrm{Fe}(\mathrm{CN})_{6}^{4-}\right]: 2 \mu M$. Sample injection: electrokinetic $(-10 \mathrm{kV}, 10 \mathrm{~s})$. Detection: direct $\mathrm{UV}$ at $220 \mathrm{~nm}$. (B) The separation of metallocyanides. Conditions as in (A), except electrolyte $\mathrm{pH}$ of 10.4 and applied voltage $-20 \mathrm{kV}$.

by potentiometric titration. He found that the most stable complexes were those formed between the most highly charged species. In other words, the stability constant of $\mathrm{Fe}(\mathrm{CN})_{6}^{4-}$ is larger than that of $\mathrm{Fe}(\mathrm{CN})_{6}^{3-}$ for the same polyammonium macrocycle, and a more stable supercomplex was formed for a larger azamacrocyle than for a smaller one $[38,39]$. Based on the property mentioned, the result of the separation is rational. In other words, this is an indirect evidence of successful incorporation of the [28] ane- $\mathrm{N}_{6} \mathrm{O}_{2}$ onto the capillary wall. So we believe that anion coordination might play an important role in this CE system.

\subsection{Separation of inorganic anions}

Some inorganic anions important in biological or environmental systems were analyzed.

\subsubsection{Effect of $p H$ and buffer composition}

Here chromate was used as a background elec- trolyte, providing suitable UV absorbance and matching the ionic mobility of inorganic anions $[40,41]$. The protonation constants of the six secondary amino groups of the macrocyclic polyamine, [28] ane $-\mathrm{N}_{6} \mathrm{O}_{2}$ determined by potentiometric method lay in the $\mathrm{pH}$ range of 6.5 to 10.7 [42], and a possible reaction is the conversion of chromate to dichromate ions below $\mathrm{pH}$ 6.0. Perhaps the most interesting $\mathrm{pH}$ range is 6.5 9.5, although the higher the $\mathrm{pH}$, the less strongly a sample anion should be retained. By buffering the background electrolyte with phosphate solution, an unexpected observation for the mobility was found at concentrations smaller than $2 \mathrm{~m} M$ and no significant difference above that concentration (Fig. 4). The ionic strength dependence of the complexation between anions and the bound ligand might explain the phenomenon. At the higher phosphate concentration, a competitive reaction between analyte and the phosphate buffer would occur, since a 10 -membered $\mathrm{N}_{3}$-cyclic amine has been used by Carey and Riggan as the ionophore for a dibasic phosphate-selective 


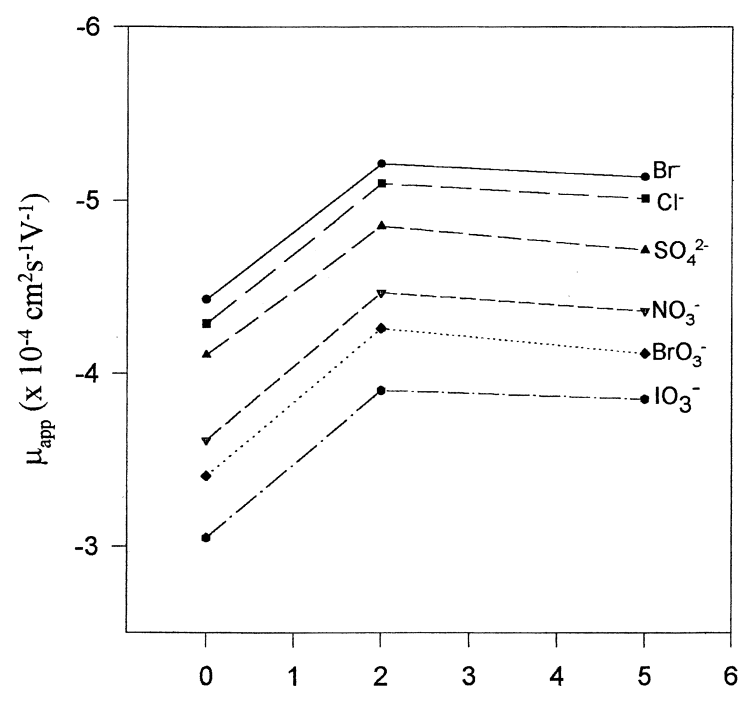

Concentration of phosphate in BGE (mM)

Fig. 4. Plot of apparent mobility versus the concentration of phosphate buffer. Column: Covalent surface modification with polyamine, [28]ane- $\mathrm{N}_{6} \mathrm{O}_{2}$ fused-silica capillary $(50 \mathrm{~cm} \times 75 \mu \mathrm{m}$ I.D.). Sample concentration: $20 \mu M$; Sample injection: $-10 \mathrm{kV}$, 10 s. Background electrolyte: chromate ( $5 \mathrm{~m} M, \mathrm{pH} 8.1$ ); Applied voltage: $-20 \mathrm{kV}$. Detection at $270 \mathrm{~nm}$.

electrode [43]. Additionally, a lower sensitivity was observed. Hence the electrolyte solution was prepared only by dissolving known amounts of sodium chromate in pure water. Before water was added to the final volumes, the $\mathrm{pH}$ was adjusted with sodium hydroxide or hydrochloric acid, and no additional buffer was used for further work. Migration behavior for sulfate, nitrite, nitrate, bromate, iodate and molybdate ions were almost identical in the selected $\mathrm{pH}$ regions, except tungstate ion (Fig. 5). Going from low to high $\mathrm{pH}$, the mobilities decrease markedly at $\mathrm{pH}<7.6$ and showed only slight difference at $\mathrm{pH}$ higher than that. Both due to the fraction of the protonated bound ligand decreases as $\mathrm{pH}$ increases. The property results a lower affinity of the anions toward the bound ligand. Meanwhile it gives a decreased EOF. Tungstate and molybdate are similar in chemical structure, but a different migration behavior was indicated. A divergence complexing ability might be the reason, since molybdate $\left(M_{\mathrm{r}}\right.$ $160)$ has much lower molecular mass than tungstate $\left(M_{\mathrm{r}} 248\right)$.

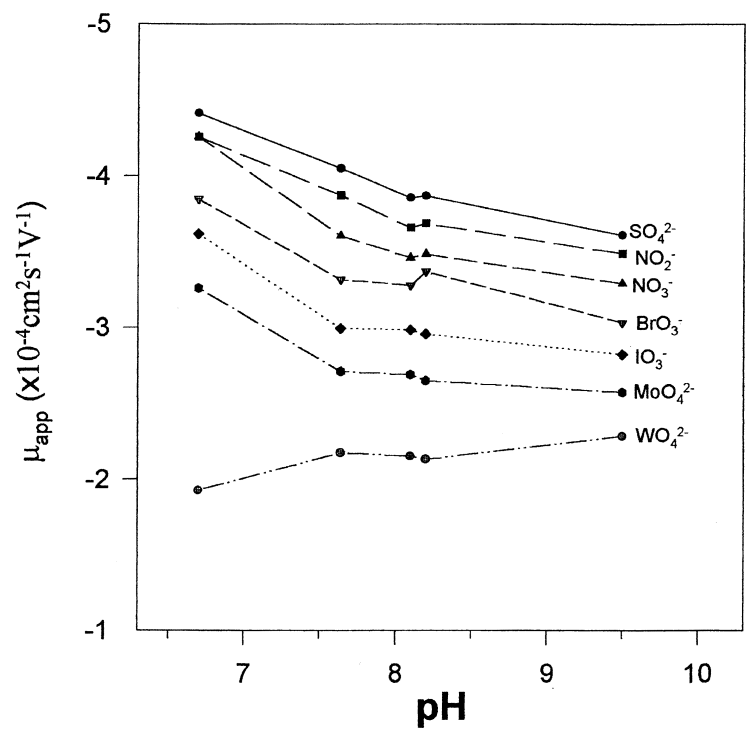

Fig. 5. Effect of $\mathrm{pH}$ on the separation of oxyanions. Column: Covalent surface modification with polyamine, [28]ane- $\mathrm{N}_{6} \mathrm{O}_{2}$ fused-silica capillary $(50 \mathrm{~cm} \times 75 \mu \mathrm{m}$ I.D.). Sample concentration: $20 \mu M$.; Sample injection: $-10 \mathrm{kV}, 10$ s. Background electrolyte: chromate $(5 \mathrm{mM})$; Applied voltage: $-20 \mathrm{kV}$. Detection at $270 \mathrm{~nm}$.

\subsubsection{Effect of electrolyte concentration}

The effect of sodium chromate concentration has been examined; the velocity increases with increasing concentration of sodium chromate (Fig. 6). This observation is similar to the one caused by increasing phosphate buffer concentration, a competitive anion complexation toward the bound ligand occurs (Fig. 4). At sodium chromate concentrations above 2.5 $\mathrm{m} M$ acceptable peak shapes were achieved. Although a higher sensitivity of the analyte was obtained with increasing concentration of sodium chromate, greater noise levels were observed. Accordingly, a sodium chromate concentration of $5 \mathrm{~m} M$ was used to achieve optimum resolution. Iodate and bromate have a smaller charge to mass ratio and therefore lower mobility. According to thermochemical radii of polyatomic ions found in the text $[44,45]$, iodate and bromate might be too small for the anion coordination (see Table 1), so the mobility decreased with increasing concentration of sodium chromate.

\subsubsection{Influence of applied potential}

A faster separation can be achieved with higher voltage, but increasing the applied potential above 


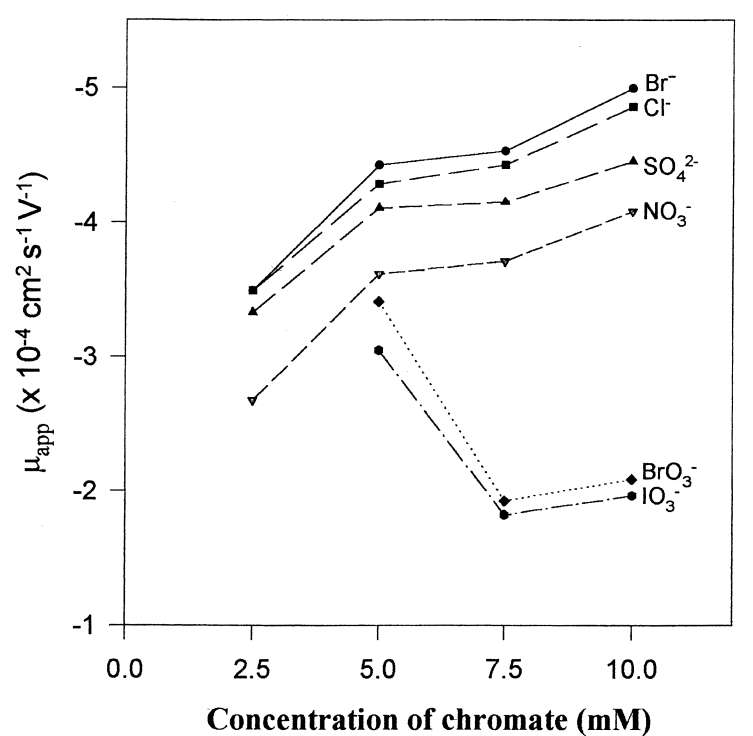

Fig. 6. Plot of apparent mobility versus the concentration of chromate. Conditions as in Fig. 5, except at $\mathrm{pH} 8.1$.

$-20 \mathrm{kV}$ resulted in baseline drift and a loss of resolution. A better resolution was demonstrated at a lower applied potential of $-10 \mathrm{kV}$.

\subsection{Analytical application}

Because several analytes exist as more than one species at lower $\mathrm{pH}$ conditions (see Table 2), a background electrolyte $\mathrm{pH}$ greater than 8 was employed for simplifying the separation conditions. Fig. 7 shows a typical electropherogram of the inorganic anions in $5 \mathrm{~m} M$ chromate at $\mathrm{pH} 8.1$. The mobility of analytes decreases in the following order: bromide $>$ chloride $>$ sulfate $>$ nitrate $>$ bromate $>$ iodate $>$ molybdate $>$ tungstate. The first six components are well resolved for easy identification and quantitation. Molybdate and tungstate being weak acids, exhibit lower mobility and a broader peak than the others. Compare with the results of Romano and Krol with CIA-Pak OFM Anion BT (patented) [46] and Stathakis and Cassidy with cationic polymer as EOF additive [6], a slight divergence in the migration order and mobility was found. The additives they used are quaternary ammonium salts and do not show the property of anion complexone, so the migration behavior can not be the same. Further compare with the results of Soga et al. to which anion migration was dependent only on their mobility [1]. The migration decreased in the order bromide $>$ iodide $>$ chromate $>$ nitrite $>$ nitrate $>$ thiocyanate $>$ molybdate $>$ tungstate $>$ bromate $>$ chlorite $>$ iodate, just reverse in our work for the pair of bromate, iodate and molybdate, tungstate. A distinct different separation mechanism for the anions can be concluded.

Table 1

Physical and chemical properties of various analytes

\begin{tabular}{|c|c|c|c|c|c|}
\hline Analyte & $M_{\mathrm{r}}$ & $\mathrm{p} K_{\mathrm{a}}$ & Radius (pm) & Effective charge ( $\mathrm{pH} 8.1)$ & Equivalent conductance $^{\mathrm{a}}$ \\
\hline Bromide & 80 & & 188 & 1 & 78.1 \\
\hline Chloride & 35.5 & & 172 & 1 & 76.35 \\
\hline Bromate & 128 & & 140 & 1 & 55.7 \\
\hline Iodate & 175 & 0.77 & 108 & 1 & 40.5 \\
\hline Chromate & 116 & $-0.2 ; 6.51$ & 242 & 1.97 & 85 \\
\hline Nitrate & 62 & & 165 & 1 & 71.42 \\
\hline Sulfate & 96 & & 244 & 2 & 80.0 \\
\hline Arsenate & 139 & $2.25 ; 6.77 ; 11.60$ & & 1.96 & 34 \\
\hline Arsenite & 107 & 9.23 & & 0.075 & \\
\hline Selenate & 143 & $-3 ; 1.66$ & 235 & 2 & 75.7 \\
\hline Molybdate & 160 & $3.55 ; 7.20$ & & 1.89 & 74.5 \\
\hline Tungstate & 248 & $3.5 ; 8.1$ & & 1.5 & 69 \\
\hline Selenite & 127 & $2.64 ; 8.27$ & 225 & 1.40 & \\
\hline Ferrocyanide & 212 & & & & $110^{\mathrm{b}}$ \\
\hline Ferricyanide & 212 & & & & $101^{\mathrm{b}}$ \\
\hline
\end{tabular}

${ }^{a}$ Limiting equivalent ionic conductance (s $\mathrm{cm}^{2}$ /equivalent): data from Refs. [40,41].

${ }^{\mathrm{b}}$ Data from Ref. [31]. 
Table 2

Summary for the separation efficiency and determination of various analytes ${ }^{\mathrm{a}}$

\begin{tabular}{|c|c|c|c|c|c|c|c|c|c|c|c|}
\hline \multirow[t]{3}{*}{ Analyte } & \multirow{3}{*}{$\begin{array}{l}\text { Migration time } \\
(\mathrm{min})\end{array}$} & \multirow{2}{*}{\multicolumn{2}{|c|}{$\begin{array}{l}\text { Separation } \\
\text { efficiency }\end{array}$}} & \multicolumn{3}{|c|}{ Precision (\% R.S.D.) } & \multicolumn{2}{|c|}{ Linearity $^{\mathrm{b}}$} & \multicolumn{3}{|c|}{ Detection limit $^{\mathrm{c}}$} \\
\hline & & & & \multirow{2}{*}{ Migration time } & \multirow{2}{*}{ Peak area } & \multirow{2}{*}{ Peak height } & \multirow{2}{*}{$\begin{array}{l}\text { Slope } \\
\left(\times 10^{3}\right)\end{array}$} & \multirow{2}{*}{$\begin{array}{l}\text { Intercept } \\
\left(\times 10^{3}\right)\end{array}$} & \multirow[t]{2}{*}{$r^{2}$} & \multirow[t]{2}{*}{$\mu M$} & \multirow[t]{2}{*}{ fmol } \\
\hline & & $N\left(\mathrm{~m}^{-1}\right)$ & $R_{\mathrm{s}}$ & & & & & & & & \\
\hline \multicolumn{12}{|c|}{ 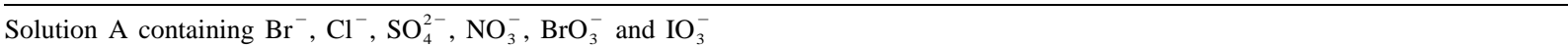 } \\
\hline $\mathrm{Br}^{-}$ & $6.5 \pm 0.2$ & 31626 & - & 3.1 & 2.5 & 3.5 & 1.47 & 7.51 & 0.9979 & 0.4 & 9.8 \\
\hline $\mathrm{Cl}^{-}$ & $6.8 \pm 0.2$ & 29450 & 1.07 & 2.9 & 3.4 & 4.1 & 2.69 & 8.85 & 0.9970 & 0.4 & 9.6 \\
\hline $\mathrm{SO}_{4}^{2-}$ & $7.2 \pm 0.2$ & 21060 & 1.02 & 2.8 & 2.9 & 3.8 & 4.60 & 10.09 & 0.9970 & 0.2 & 4.8 \\
\hline $\mathrm{NO}_{3}^{-}$ & $8.1 \pm 0.3$ & 15270 & 2.46 & 3.0 & 3.9 & 3.8 & 1.34 & 8.22 & 0.9956 & 0.5 & 9.5 \\
\hline $\mathrm{BrO}_{3}^{-}$ & $8.6 \pm 0.3$ & 10725 & 1.20 & 3.3 & 3.7 & 3.2 & 1.09 & 7.25 & 0.9965 & 0.5 & 8.1 \\
\hline $\mathrm{IO}_{3}^{-}$ & $9.6 \pm 0.3$ & 10058 & 2.02 & 3.1 & 4.0 & 4.5 & 0.84 & 4.43 & 0.9938 & 0.5 & 5.9 \\
\hline \multicolumn{12}{|c|}{ Solution $\mathrm{B}$ containing $\mathrm{SeO}_{4}^{2-}$ and $\mathrm{SeO}_{3}^{2-}$} \\
\hline $\mathrm{SeO}_{4}^{2-}$ & $6.9 \pm 0.2$ & 16980 & - & 2.9 & 2.1 & 2.9 & 3.55 & 5.31 & 0.9970 & 0.2 & 5.0 \\
\hline $\mathrm{SeO}_{3}^{2-}$ & $9.0 \pm 0.3$ & 11951 & 5.22 & 3.1 & 3.6 & 4.0 & 2.10 & 2.36 & 0.9952 & 0.4 & 9.1 \\
\hline
\end{tabular}

${ }^{a}$ Capillary: [28]ane $-\mathrm{N}_{6} \mathrm{O}_{2}$ bonded phase; column dimension: $70 \mathrm{~cm}$ (effective length $\left.50 \mathrm{~cm}\right) \times 75 \mu \mathrm{m}$ I.D., background electrolyte: chromate ( $5 \mathrm{mM}$, pH 8.1); applied potential: $-20 \mathrm{kV}$; detection at $270 \mathrm{~nm}$; sample injection: electrokinetic $(-10 \mathrm{kV}, 10 \mathrm{~s})$.

${ }^{\mathrm{b}}$ Confidence level of $95 \%(n=3)$.

${ }^{\mathrm{c}}$ Detection limit: based on three times signal-to-noise ratio. $N=$ (No. of theoretical plate); $R_{\mathrm{s}}=$ (resolution).

\subsubsection{Calibration and detection limits}

The calibration graphs of peak area against anion concentrations in the sample mixture (as Fig. 7) are given in Table 2 with the respective regression coefficients. Linearity is over the range of $10^{-5} \sim$ $10^{-6} M$ and the detection limit based on three times signal-to-noise ratio is $4.8 \sim 9.8$ fmol. The relative standard deviations (R.S.D.) of the migration time

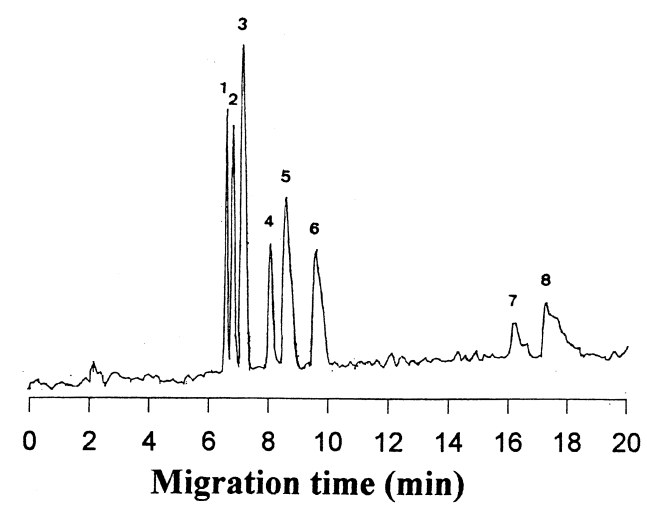

Fig. 7. Electrophoretic separation of inorganic anions. Column: Covalent surface modification with polyamine, [28]ane- $\mathrm{N}_{6} \mathrm{O}_{2}$ fused-silica capillary $(50 \mathrm{~cm} \times 75 \mu \mathrm{m}$ I.D.). Sample concentration: $20 \mu M$; Sample injection: $-10 \mathrm{kV}, 10 \mathrm{~s}$. Background electrolyte: chromate ( $5 \mathrm{mM}, \mathrm{pH} 8.1)$; Applied voltage: $-20 \mathrm{kV}$. Detection at $270 \mathrm{~nm}$. Peaks: 1 . bromide; 2. chloride; 3. sulfate; 4. nitrate; 5. bromate; 6 . iodate; 7 . molybdate; 8 . tungstate. (three measurements) is better than $3.0 \%$, those of peak area and peak height are both less than $4.5 \%$. Although the reproducibility seems not better than the uncoated system. The prepared column are stable for longer than four months in continuous use. In addition, only $0.001 \mathrm{M} \mathrm{NaOH}$ was needed for the regeneration of the column. We attribute the success to two steps only in the preparation of the covalent bounding capillary column. The separation efficiencies obtained are in the range of 10000 to 31000 plates $\mathrm{m}^{-1}$ for the samples analyzed (Table 2).

\subsubsection{Speciation of arsenic and selenium derivatives}

Separation of arsenic and selenium oxyanions is important in the determination of toxicological effects of each. Fig. 8A and B are pherograms of arsenate and selenate species using chromate electrolyte at $\mathrm{pH}$ 8.1. Excellent resolution for the determination of these selenium species was achieved utilizing $10 \mathrm{~s}$ electrokinetic injections at $-10 \mathrm{kV}$. Calibration curves with selenate yielded a stronger detector response than selenite (Table 2). Arsenate and dimethylarsinic acid were eluted earlier and well separated, but arsenite and phenylarsonic acid were coeluted thereafter. Therefore phthalate buffer (2 $\mathrm{m} M, \mathrm{pH}$ 5.6) was used instead. At the applied potential of $-20 \mathrm{kV}$, the mixture of arsenate, 


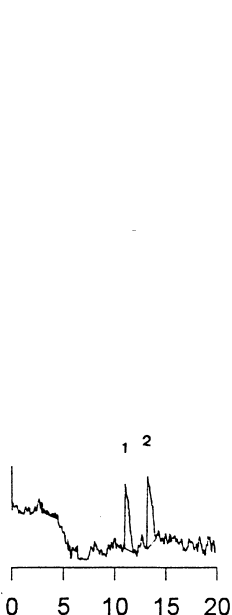

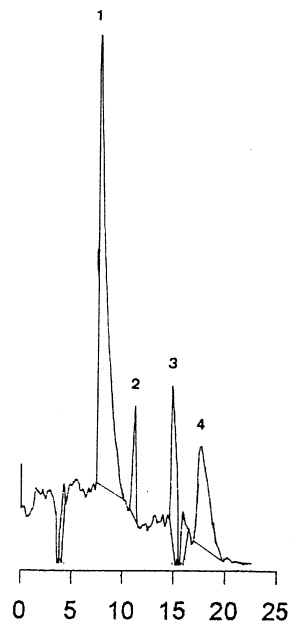

Migration (min)

Fig. 8. Electropherograms of arsenic and selenium species. Conditions as in Fig. 7, except sample concentrations of $10 \mu M$ for $\mathrm{A}$ and $\mathrm{B}$, sample concentration of $20 \mu M$ and background electrolyte of phthalate (2 $\mathrm{m} M, \mathrm{pH} \mathrm{5.6})$ for C. Peaks: (A) 1. arsenate; 2. arsenite; (B) 1. selenate; 2. selenite; (C) 1. arsenate; 2. phenylarsonic acid; 3. arsenite; 4. dimethylarsinic acid.

phenylarsonate, arsenite and dimethylarsinate could be well separated within $18 \mathrm{~min}$ (Fig. 8C). On the whole, the prepared capillary column and the established condition appear to be a useful method for the analysis of arsenic and selenium species.

\subsubsection{Application to mineral water and rainwater}

Mineral water ( $\mathrm{pH}$ 7.0) from the supermarket and rainwater ( $\mathrm{pH}$ 5.3) on the campus were sampled and analyzed using the established conditions. Both samples were passed through a $0.45 \mu \mathrm{m}$ membrane filter and only mineral water was diluted prior to the analysis. Fig. 9A and B show the electropherograms of the mineral and rainwater, respectively. Standard addition method was used for the peak identification (Table 3). It was found that there are chloride, sulfate, nitrate and carbonate in the samples, where carbonate was not quantitied due to the broden peak. The separation efficiency in mineral water is quite good. While the migration time of each analyte is very different between mineral water and rain water. The phenomenon might be due to the matrix effect and partially due to the sample introduction error.

A

B

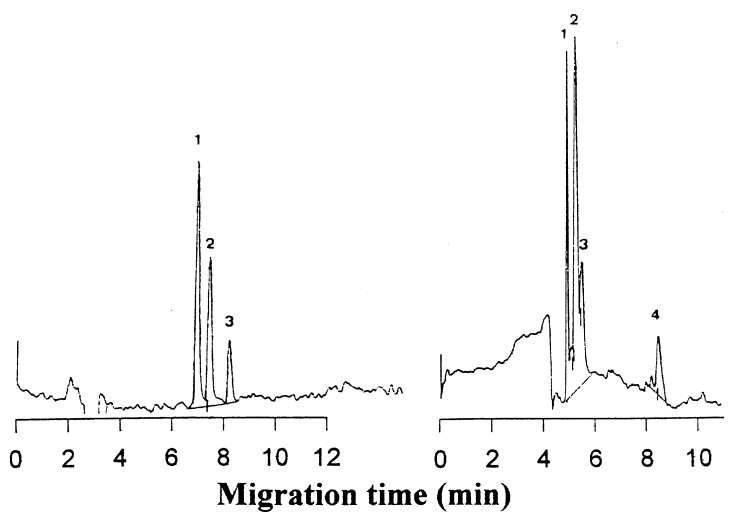

Fig. 9. Electropherograms for the separation of anions in real samples. Conditions as in Fig. 7.; (A) mineral water; (B) rainwater. Peaks: 1 . chloride; 2. sulfate; 3 . nitrate; 4. carbonate.

\section{Conclusions}

Compared to macrocyclic polyethers, a fundamentally different feature of macrocyclic polyamines is their ability to take up protons to form polycation macrocycles. This unique characteristic of macrocyclic polyamines would promise the design of a variety of anion receptors if the ring size of the charge density of the protonated polyamine host molecules are properly tailored to meet the desired host-guest interactions. In a previous paper we have prepared a novel wall-coated [24]ane- $\mathrm{N}_{6}$ fused-silica for the electrophoretic separation of both organic and inorganic anions [30]. Since the selectivity of complexation depends both on electrostatic and structural effects, modification of size and shape of the macrocyclic system should allow control of the selectivity sequence. In the present study, we have prepared a new capillary column incorporating a 28 -membered macrocyclic polyamine for the electrophoretic separation of simple anions, oxyanions and metallocyanides. Most of the data confirm the assumption that selectivity of the system is mainly based on anion complexation behavior. In this work, neutral marker migrates very slow and a lengthy time was necessary to detect it. So $\mu_{\text {app }}$ and not $\mu_{\text {ep }}$ was provided in ordinate for the plotting (Figs. 4-6). 
Table 3

Determination of inorganic anions in real samples ${ }^{a}$

\begin{tabular}{lllll}
\hline Sample $^{\mathrm{b}}$ & Chloride & Sulfate & Nitrate & Carbonate \\
\hline Mineral water $\left(\mathrm{mg} \mathrm{l}^{-1}\right)$ & $8.0 \pm 0.3(8.4)^{\mathrm{c}}$ & $7.2 \pm 0.4(6.9)$ & $6.0 \pm 0.2(6.3)$ & - \\
Rainwater $\left(\mathrm{mg} \mathrm{l}^{-1}\right)$ & $0.26 \pm 0.01$ & $1.06 \pm 0.04$ & $0.76 \pm 0.07$ & $-{ }^{\mathrm{d}}$ \\
\hline
\end{tabular}

${ }^{a}$ Column: covalent surface modification with polyamine, [28]ane- $\mathrm{N}_{6} \mathrm{O}_{2}$ fused-silica capillary $(50 \mathrm{~cm} \times 75 \mu \mathrm{m}$ I.D. $)$;sample injection: $-10 \mathrm{kV}$, $10 \mathrm{~s}$; background electrolyte: chromate $(5 \mathrm{mM}$, pH 8.1); applied voltage: $-20 \mathrm{kV}$; detection at $270 \mathrm{~nm}$.

${ }^{\mathrm{b}}$ Number of measurements: 3, confidence level of 95\%; 1/10 dilution for mineral water; $\mathrm{pH}$ of rain water (5.3).

${ }^{\mathrm{c}}$ The data in parenthesis are claimed by the manufacture.

${ }^{\mathrm{d}}$ Carbonate was found in the sample but not quantitied.

In the proposed method only simple electrolyte was needed. Not only oxyanions but also selenium and arsenic speciation as well as metallocyanides could be analyzed within a short time. A poor sensitivity occurring in conventional $\mathrm{CE}$ with a coating reagent and indirect detection can be overcome. The column is highly stable and shows great potential for making measurements in environmental monitoring. Not only inorganic but also organic anions could be separated with the prepared column. The determination of aliphatic as well as aromatic organic anions is now in progress.

\section{Acknowledgements}

The authors thank the National Science Council of Taiwan for financial support.

\section{References}

[1] T. Soga, Y. Inoue, G.A. Ross, J. Chromatogr. A. 718 (1995) 421.

[2] N.J. Benz, J.S. Fritz, J. Chromatogr. A. 671 (1994) 437.

[3] X. Huang, J.A. Luckey, M.J. Gordon, R.N. Zare, Anal. Chem. 61 (1989) 766.

[4] T. Tsuda, J. High Resolut. Chromatogr. Chromatogr. Commun. 10 (1987) 622.

[5] G.W. Tindall, R.L. Perry, J. Chromatogr. A. 696 (1995) 349.

[6] C. Stathakis, R.M. Cassidy, Anal Chem. 66 (1994) 2110.

[7] T. Takayanagi, E. Wada, S. Motomizu, Anal. Sci. 12 (1996) 575.

[8] J.D. Lamb, B.R. Edwards, R.G. Smith, R. Garrick, Talanta. 42 (1995) 109.

[9] C.S. Chiou, J.S. Shih, Analyst. 121 (1996) 1107.

[10] J.W. Jorgenson, K.D. Lukacs, J. Chromatogr. 218 (1981) 209.

[11] J.H. Knox, I.H. Grant, Chromatographia. 24 (1987) 135.
[12] J.H. Knox, I.H. Grant, Chromatographia. 32 (1991) 317.

[13] G.J.M. Bruin, P.P.H. Tock, J.C. Kraak, H. Poppe, J. Chromatogr. 517 (1990) 557.

[14] P. Narang, L.A. Colon, J. Chromatogr. A. 773 (1997) 65.

[15] A.L. Crego, A. Gonzalez, M.L. Marina, Crit. Rev. Anal. Chem. 26 (1996) 261.

[16] L.A. Colon, Y. Guo, A. Fermier, Anal. Chem. 69 (1997) $461 \mathrm{~A}$.

[17] R. Swart, J.C. Kraak, H. Poppe, J. Chromatogr. A. 670 (1994) 25.

[18] R. Swart, J.C. Kraak, H. Poppe, J. Chromatogr. A. 689 (1995) 177.

[19] R. Swart, J.C. Kraak, H. Poppe, Chromatographia. 40 (1995) 587.

[20] D. Li, H.H. Knobel, V.T. Remcho, J. Chromatogr. B. 695 (1997) 169.

[21] Y. Guo, L.A. Colon, Anal. Chem. 67 (1995) 2511.

[22] Z.J. Tan, V.T. Remcho, Anal. Chem. 69 (1997) 581.

[23] Y. Ruan, G. Feenstra, J.C. Kraak, H. Poppe, Chromatographia. 35 (1993) 597.

[24] A.L. Crego, J. Diez-Mass, M. Dobrio, Anal. Chem. 65 (1993) 1615.

[25] Z.J. Tan, V.T. Remcho, J. Microcol. Sep. 10 (1998) 99.

[26] D.M. Dohmeier, J.W. Jorgenson, J. Microcol. Sep. 3 (1991) 317.

[27] J.M. Lehn, Science. 227 (1985) 849.

[28] A. Domenech, E. Garcia-Espana, J.A. Ramirez, Talanta. 42 (1995) 1663.

[29] Q. Lu, J.J. Reibenspies, A.E. Martell, R.J. Motekaitis, Inorg. Chem. 35 (1996) 2630.

[30] J.C. Hsu, W.H. Chen, C.Y. Liu, Analyst. 122 (1997) 1393.

[31] D.C. Harris, Quantitative Chemical Analysis, W.H. Freeman, New York, 1995.

[32] N.A. Guzman, Capillary Electrophoresis Technology, Marcel Dekker, New York, 1993.

[33] J. Kohr, H. Engelhardt, J. Chromatogr. A. 652 (1993) 309.

[34] J.M. Lehn, Helv. Chim. Acta. 66 (1983) 1262.

[35] M. Kodama, E. Kimura, S. Yamaguchi, J. Chem. Soc. Dalton Trans. 12 (1980) 2536.

[36] B. Dietrich, M.W. Hosseini, J.M. Lehn, R.B. Sessions, J. Am. Chem. Soc. 103 (1981) 1282.

[37] W. Buchberger, P.R. Haddad, J. Chromatogr. A. 687 (1994) 343.

[38] J. Arago, A. Bencini, A. Bianchi, A. Domenech, E. GarciaEspana, J. Chem. Soc. Dalton Trans. 2 (1992) 319. 
[39] M.W. Hosseini, in: A.F. Williams, C. Floriani, A.E. Merbach, (Eds.), Perspectives in Coordination Chemistry, $\mathrm{VCH}$, New York, 1992, pp. 333-344.

[40] J.A. Dean, Lange's Handbook of Chemistry, McGraw-Hill, New York, 1985.

[41] R.C. Weast, Handbook of Chemistry and Physics, CRC Press, Boca Raton, FL, 66th ed., 1985, p. D-168.
[42] W.H. Chen, C.Y. Liu, unpublished work.

[43] C.M. Carey, W.B. Riggan Jr., Anal. Chem. 66 (1994) 3587.

[44] J.E. Huheey, Inorganic Chemistry-Principles of Structure and Reactivity, Harper and Row, New York, 3rd ed., 1983, p. 78.

[45] H.D.B. Jenkins, K.P. Thakur, J. Chem. Educ. 56 (1979) 576.

[46] J.P. Romano, J. Krol, J. Chromatogr. 640 (1993) 403. 